\title{
TECTA Gene
}

National Cancer Institute

\section{Source}

National Cancer Institute. TECTA Gene. NCI Thesaurus. Code C114416.

This gene plays a role in hearing. 